\title{
Intraepithelial lymphocytes of human gut: isolation, characterisation and study of natural killer activity
}

\author{
NADINE CERF-BENSUSSAN，DELPHINE GUY-GRAND，AND C GRISCELLI
}

From the Group of Pediatric Immunology and Rheumatology, INSERM U 132, Hôpital des Enfants Malades, Paris, France

SUMmaRY A method using a mechanical procedure for isolation of lymphocytes from the epithelium of human intestinal mucosa allows the study of some of their characteristics and functions. Most of the isolated cells are of the $\mathrm{T}$ lineage $\left(\mathrm{E}+\right.$ and $\left.\mathrm{T}_{3}+\right)$ and express the phenotype associated with cytotoxic-suppressor $T$ cells $\left(T_{8}\right)$. A large number contain intracytoplasmic granules. Granules are stained with alcian blue $(\mathrm{pH} \mathrm{2 \cdot 2)}$, are metachromatic with Toluidine blue (pH 4) and some are shown to incorporate ${ }^{35}$ sulphate, suggesting that they contain sulphated mucopolysaccharides. As these cells are similar in many respects to the large granular lymphocytes that mediate natural killer activity in the peripheral blood, their natural cytotoxicity was tested against K 562 target cells. No activity was detected among the human intraepithelial lymphocytes and treatments with known potentiators of natural killer activity, ie, interferon or PHA-depleted conditioned medium containing Il-2, failed to reveal any cytotoxic activity.

The intestinal mucosa contains a large number of lymphocytes distributed in the epithelium, in the lamina propria and in the Peyer's patches. Characterisation of intraepithelial lymphocytes isolated from animals has shown that they are a unique lymphoid population with the predominant phenotype associated with cytotoxic-suppressor $\mathrm{T}$ cells, ${ }^{1-3}$ and that they contain intracytoplasmic granules. ${ }^{13-5}$ Studies of frozen tissue sections have indicated that human intraepithelial lymphocytes possess a similar phenotype ${ }^{67}$ as well as intracytoplasmic granules demonstrable by electron microscopy. ${ }^{89}$

Attempts to isolate pure intraepithelial lymphocytes for functional studies from human intestinal epithelium have been hampered by contaminating lamina propria or Peyer's patches lymphocytes as evidenced by the presence of numerous B cells, not detected in the epithelium in situ. ${ }^{10}{ }^{11}$ In this paper we describe an isolation procedure which yields an intraepithelial lymphocyte population with characteristics similar to those observed within tissue sections.

The in vivo function of intraepithelial lymphocytes is still unknown. That they may participate in the mucosal immune defence is suggested by low

Address for correspondence: Nadine Cerf-Bensussan, Group of Pediatric Immunology and Rheumatology, INSERM U 132, Hôpital des Enfants Malades, 149 rue de Sèvres, 75743 Paris CEDEX 15. France.

Received for publication 13 April 1984 number in germ free animals, ${ }^{1}{ }^{12}$ and the frequency of digestive diseases in $T$-immunodeficient patients. ${ }^{13}$ They are increased in several enteropathies such as coeliac disease, ${ }^{714}$ cow's milk intolerance, ${ }^{15}$ and in graft-versus-host disease, where some evidence suggests their involvement in a cellular reaction responsible for epithelial damage. ${ }^{1617}$ Recently, their morphological similarity with the peripheral blood large granular lymphocytes that mediate natural killer activity ${ }^{18}$ has suggested that intraepithelial lymphocytes may be natural killer cells. Studies of intraepithelial lymphocytes isolated from different species for natural killer activity, however, have given conflicting results. Natural killer activity was detected among guinea pig $^{5}$ and mouse ${ }^{19} 20$ intraepithelial lymphocytes. In contrast, human lymphocytes isolated from the colonic epithelium did not show any spontaneous cytotoxicity against Chang target cells but the use of EDTA during the isolation procedure in that report may have impaired natural cytotoxicity. ${ }^{11}$ In the present study, natural killer activity of intraepithelial lymphocytes was tested against K 562 targets. The effects of antagonists of histamine or prostaglandins, which may be released during the isolation procedure and may impair cytotoxicity 22 have been examined, as have the effects of lymphokines, interferon, or interleukin 2 capable of enhancing the natural killer activity. 2324 


\section{Methods}

\section{MATERIALS}

Intestinal samples

All samples were obtained from 20 patients aged 20 to 80 years, 16 of whom underwent small bowel resection for cancer (colonic, gastric, or pancreatic), two for inflammatory bowel diseases (Crohn's disease and ulcerative colitis) and one each for an appendix abscess and mesenteric infarction. The patient with Crohn's disease had steroid therapy (1 $\mathrm{mg} / \mathrm{kg} / \mathrm{day}$ ) for three weeks before surgery. In each case the intestinal sample was taken as far as possible $(>5 \mathrm{~cm})$ from any macroscopically detectable lesion and was histologically normal. In addition, peripheral blood samples obtained from two patients and from healthy volunteers were studied.

\section{Isolation of intraepithelial lymphocytes}

Subsequent to resection, intestinal samples were immediately placed in Hank's balanced salt solution (Gibco, Glasgow, Scotland) containing antibiotics (penicillin-G $10000 \mathrm{U} / 1$ and streptomycin $1 \mathrm{~g} / \mathrm{l}$, Specia Lab, France), cut longitudinally, spread out and washed. Mucus was gently removed using a rubber policeman before the mucosa was scraped down to the muscularis with a scalpel. Mucosal fragments were incubated with constant stirring for 20 minutes at room temperature in 199 medium (Gibco) containing 20\% heat inactivated human $\mathrm{AB}$ serum and $1 \mathrm{mM}$ dithioerythritol (Sigma, Saint Louis, Mi, USA). The fragments were then centrifuged at $400 \mathrm{~g}$, resuspended in Hank's balanced salt solution containing antibiotics and $10 \%$ human serum (medium used for all further steps) and vortexed for three minutes. After sedimentation at room temperature for 30 minutes, the supernatant was centrifuged at $400 \mathrm{~g}$, resuspended and passed rapidly (within four minutes) through a glass wool column at room temperature. Columns were prepared with $0.8 \mathrm{~g}$ glass wool (Sovirel, France), packed in $20 \mathrm{ml}$ syringes and washed with $30 \mathrm{ml}$ Hank's balanced salt solution with $1 \mathrm{mg} / \mathrm{ml}$ Hepes (Calbiochem Lab, San Diego, Ca, USA).

Non-adherent cells were washed, resuspended in medium and centrifuged in 11 cases over Ficoll Isopaque (Pharmacia, Sweden) (density $1.09,800 \mathrm{~g}$, $20^{\circ} \mathrm{C}$ for 20 minutes). Cells were collected at the Ficoll-Hank's balanced salt solution interface. The yield of lymphocytes (90\% viability) was variable (Table 1) and they were highly contaminated by epithelial cells (26\% jejunum, $45 \%$ ileum). As most isolated intraepithelial lymphocytes form rosettes with sheep erythrocytes $(E+)$ (Table 1), further

Table 1 Characteristics of isolated human intraepithelial lymphocytes

\begin{tabular}{|c|c|c|c|c|c|c|c|c|}
\hline \multirow{2}{*}{$\begin{array}{l}\text { Origin of } \\
\text { gut mucosa }\end{array}$} & \multirow{2}{*}{$\begin{array}{l}\text { Recovered } \\
\text { lymphocytes } \\
10^{-5} / \mathrm{cm}^{2} \text { (no) }\end{array}$} & \multirow{2}{*}{$\begin{array}{l}\text { Granular } \\
\text { lymphocytes } \\
(\%)\end{array}$} & \multirow[b]{2}{*}{$E(+)$} & \multicolumn{3}{|c|}{$T$-cell subsets (\%) } & \multicolumn{2}{|c|}{ B lymphocytes (\%) } \\
\hline & & & & $T 3+$ & $T 8+$ & $T 4+$ & ilg & $s I g$ \\
\hline \multirow[t]{10}{*}{ Ileum } & $3 \cdot 8$ & 20 & \multirow[t]{2}{*}{58} & & & & $0 \cdot 3$ & 2 \\
\hline & $8 \cdot 2$ & 10 & & & & & $0 \cdot 2$ & 0.7 \\
\hline & $7 \cdot 7$ & 12 & 53 & & & & $0 \cdot 8$ & 2 \\
\hline & 9 & 30 & 60 & & & & $0 \cdot 1$ & 0.5 \\
\hline & 14 & 31 & 80 & 65 & 52 & 10 & $0 \cdot 3$ & 0.9 \\
\hline & $1 \cdot 2$ & 7 & & 55 & 41 & 10 & & \\
\hline & $1 \cdot 5^{*}$ & 15 & & 85 & 70 & 16 & & \\
\hline & $1^{*}$ & 38 & & 83 & 54 & & & \\
\hline & $3 \cdot 5^{*}$ & 29 & & 94 & 79 & & & \\
\hline & $4^{*}$ & 30 & 75 & 91 & 60 & 22 & & 2 \\
\hline \multicolumn{2}{|c|}{ Mean $\pm S D$ in ileum } & $22 \cdot 2 \pm 10 \cdot 7$ & $65 \cdot 2 \pm 11 \cdot 2$ & $78 \cdot 8 \pm 15 \cdot 4$ & $59 \cdot 3 \pm 13 \cdot 6$ & $14 \cdot 5 \pm 5 \cdot 7$ & $0.3 \pm 0.3$ & $1 \cdot 3 \pm 0 \cdot 7$ \\
\hline \multirow[t]{10}{*}{ Jejunum } & 50 & 20 & 60 & & & & $0 \cdot 1$ & $0 \cdot 3$ \\
\hline & 120 & 35 & 64 & 90 & 83 & 7 & $0 \cdot 2$ & $0 \cdot 3$ \\
\hline & 300 & 45 & 80 & & & & $0 . \overline{5}$ & \\
\hline & $9 \cdot 5$ & 3 & 70 & 70 & 65 & 8 & 0.2 & $0 \cdot 3$ \\
\hline & 47 & 20 & 80 & 75 & 58 & 10 & $0 \cdot 3$ & 0.4 \\
\hline & $138^{*}$ & 54 & 71 & 81 & 53 & 7 & & \\
\hline & $25^{*}$ & 34 & & 91 & 75 & 3 & $0 \cdot 1$ & $0 \cdot 1$ \\
\hline & $139^{*}$ & 15 & & 98 & 87 & 5 & & \\
\hline & $21^{*}$ & 15 & & 98 & 90 & 10 & & \\
\hline & $43^{*}$ & 10 & & 97 & 80 & 14 & & \\
\hline \multicolumn{2}{|c|}{ Mean $\pm S D$ in jejunum } & $25 \cdot 5 \pm 16 \cdot 3$ & $70 \cdot 8 \pm 8 \cdot 2$ & $87 \cdot 5 \pm 10 \cdot 9$ & $73 \cdot 9 \pm 13 \cdot 7$ & $8 \pm 3 \cdot 4$ & $0 \cdot 2 \pm 0 \cdot 1$ & $0 \cdot 3 \pm 0 \cdot 2$ \\
\hline \multicolumn{2}{|c|}{ Mean $\pm S D$ in small intestine } & $23 \cdot 6 \pm 13 \cdot 5$ & $68 \cdot 3 \pm 9 \cdot 8$ & $83 \cdot 8 \pm 13 \cdot 3$ & $67 \cdot 6 \pm 15 \cdot 1$ & $10 \cdot 2 \pm 5 \cdot 1$ & $0 \cdot 3 \pm 0 \cdot 2$ & $0.8 \pm 0.7$ \\
\hline
\end{tabular}

* Isolation on discontinuous Percoll gradient.

Other studies were performed after isolation on Ficoll-Hypaque. 
separation from contaminating epithelial cells was attempted using sedimentation of E+ cells using a technique previously described. ${ }^{25}$ This provided an almost pure, albeit selected, lymphocyte population. Lymphocytes obtained with this procedure were therefore not used for natural killer studies.

In nine cases, non-adherent cells were purified on a discontinuous gradient of Percoll (Pharmacia) as described by Tagliabue et al. ${ }^{19}$ Among the five discontinuous gradient layers $(30,40,55,70,80 \%)$ generated by test samples, the two lowest layers contained numerous red blood cells and very few lymphocytes, while the upper layer contained dead cells and debris. The second layer contained about 65\% epithelial cells and 35\% lymphocytes (about $30 \%$ of all collected lymphocytes) whereas the middle layer, collected for all further experiments, contained about $95 \%$ lymphocytes with a viability above $98 \%$ (about $70 \%$ of all collected lymphocytes).

Isolation was achieved within six hours after removal of the surgical specimen.

Lymphocytes obtained using both separation methods were similar with respect to their size (medium-sized lymphocytes) and to the percentage of granular cells and of rapidly dividing cells labelled after one hour incubation with tritiated thymidine ${ }^{1}$ (see below). In addition, the distribution of the membrane markers was identical (data not shown).

Peripheral blood lymphocytes used as control were isolated by the same procedure as used for intraepithelial lymphocytes: they were passed through an identical glass wool column, and were centrifuged over Ficoll Isopaque, or Percoll gradient concomitantly with intraepithelial lymphocytes.

\section{Characterisation of intraepithelial lymphocytes} Cytological studies and histochemical procedures were performed on cytocentrifuged smears which were air-dried, fixed in absolute ethanol and stained with May-Grunwald-Giemsa, alcian blue at $\mathrm{pH} 0.3$ and $2 \cdot 2$, or toluidine blue at $\mathrm{pH} 0.3$ and 4 . For intracellular histamine detection, non-fixed slides were treated by orthophtaldialdehyde as previously described. ${ }^{1}$

E rosettes were prepared at $4^{\circ} \mathrm{C}$ with neuraminidase-treated sheep red blood cells by a modification of the method of Wigzell. ${ }^{25}$ Erythrocyte antibody complement (EAC) rosettes were prepared using the method of Bianco et al. $^{26}$

Immunofluorescence staining was performed on isolated cells ${ }^{27}$ using: (1) rhodamine-conjugated $\mathrm{F}(\mathrm{ab})^{\prime} 2$ fragments of goat anti-human immunoglobulin antiserum (1:10) (FGaHu TRITC, Nordic,
London, UK) for detection of membrane immunoglobulins (sIg). (2) A goat fluoresceinconjugated anti-human Ig (1:6) (Meloy, Springfield, $\mathrm{Vi}$, USA) for intracytoplasmic staining of centrifuged cells fixed with absolute methanol. (3) Monoclonal antibodies (MA) directed to $T$ cell subsets (anti-T3, T4, T8. Orthopharmaceutical, Raritan, NJ, USA), ${ }^{28}$ to non-polymorphic regions of human Ia-like antigen (anti-DR, Sera-Lab, Crowley Dawn, Sussex, UK) or reactive with monocytes, natural killer cells and granulocytes (anti-M $\mathbf{M}_{1}$, Orthopharmaceutical). ${ }^{29}{ }^{30}$ Culture supernatants were used at a 1:6 final dilution for anti-T8, $M_{1}$ or DR MA and at 1:4 for anti- $T_{3}$ or $\mathrm{T}_{4}$ MA. A rhodamine-conjugated goat anti-mouse immunoglobulin antiserum (Gamig TRITC, Nordic) was used at a 1:6 dilution to reveal the MA fixation. Previous to membrane staining, lymphocytes were incubated for 30 minutes at $37^{\circ} \mathrm{C}$ in culture medium in order to eliminate cytophilic immunoglobulins, then for one hour in ice to prevent capping. In some experiments, cells were incubated for 18 hours in serum supplemented medium before study. After this incubation, the distribution of $\mathrm{T}$ cell markers was not modified but membrane immunofluorescent staining was brighter. Cytocentrifuged smears were examined with a vertical Opak fluor illuminator and phase contrast, under a Leitz Orthoplan microscope.

Membrane immunofluorescent staining was coupled with lymphocyte labelling with ${ }^{35}$ sulphate as follows: $2 \times 10^{6}$ lymphocytes were incubated in $2 \mathrm{ml}$ serum supplemented culture medium with $400 \mu \mathrm{Ci}$ ${ }^{35} \mathrm{~S}$ (sodium sulphate specific activity $>5 \mathrm{mCi} / \mu \mathrm{g}$, Amersham, Versailles, France) for 18 hours. Cells were then washed three times in Hank's and incubated in ice for one hour before performing membrane staining with anti-T3, T4 or T8 monoclonal antibody. Cytocentrifuged smears were fixed in absolute ethanol. Slides were dipped in a photographic emulsion (Ilford K5, Essex, UK) and exposed at $4^{\circ} \mathrm{C}$ for two, five, or seven days before being revealed. Labelled lymphocytes were detected on phase contrast (only cells containing a cluster of three or more silver grains were considered as positive) and concomitantly screened for membrane immunofluorescence. The background was low enough after a two, or five day exposure for easy detection of ${ }^{35} \mathrm{~S}$ labelled cells. For detection of rapidly dividing cells, intraepithelial lymphocytes were incubated for one hour with tritiated thymidine as previously described. ${ }^{1}$

Cytotoxicity against the $K 562$ cell line

Intraepithelial lymphocytes or control peripheral blood lymphocytes were tested either immediately 
after isolation, or after an 18 hour incubation in RPMI containing 10\% human serum and antibiotics. In some experiments, $10 \mathrm{U} / \mathrm{ml}$ interferon (Leucocyte Sendai virus induced interferon, Institut Pasteur, France) or culture supernatant of PHA stimulated lymphocytes which was PHA-depleted and contained IL-2 (10\% final dilution, Bethesda Research Lab, USA) were added to the culture medium during the overnight incubation. Lymphocytes were then washed twice, enumerated in trypan blue and resuspended in RPMI as above.

Cytotoxicity was evaluated in a four hour ${ }^{51}$ chromium release assay as described by Lipinski $e t$ $a l .{ }^{31}$ Cytotoxicity index was calculated by the following formula:

$$
\% \text { cytotoxicity }=\frac{- \text { Experimental }{ }^{51} \mathrm{Cr} \text { release }}{\text { Total radiontaneous }{ }^{51} \mathrm{Cr} \text { release }}
$$

Spontaneous release was less than $10 \%$ in all cases.

In some experiments, isolation of intraepithelial lymphocytes was performed from the beginning of the isolation procedure in presence of either indomethacin $\left(5 \cdot 10^{-7} \mathrm{M}\right)$ or cimetidine $\left(10^{-3} \mathrm{M}\right)$.

\section{Results}

\section{NUMEROUS INTRAEPITHELIAL LYMPHOCYTES CONTAIN INTRACYTOPLASMIC GRANULES}

Smears stained with May-Grunwald-Giemsa indicated that cell preparations obtained either by Ficoll, or by Percoll separation, contained about $80 \%$ medium-sized lymphocytes with abundant blue cytoplasm and a crescentic nucleus and $20 \%$ small lymphocytes with scanty blue cytoplasm and a round dark nucleus. An average value of $24 \% \pm 13 \%$ (range 3-54\%) of intraepithelial lymphocytes contained intracytoplasmic violet granules of variable size (Figure). A comparable number of granular lymphocytes was seen in the jejunum $(25 \%)$ and in the ileum (22\%) (Table 1). Granules were only seen in the medium sized lymphocytes and were often clustered in the concavity of the nucleus. Most lymphocytes contained two or three granules but the number varied from one to 15 per cell. Those granules stained with May-GrunwaldGiemsa were also stained with alcian blue at $\mathrm{pH} 2 \cdot 2$ or with toluidine blue at $\mathrm{pH} 4$ with metachromasia, but only rarely with alcian blue, or toluidine blue at $\mathrm{pH} 0 \cdot 3$. The orthophtaldialdehyde reaction, positive in the presence of histamine, was negative in intraepithelial lymphocytes obtained from five different individuals.

Intraepithelial lymphocytes have a low rate of

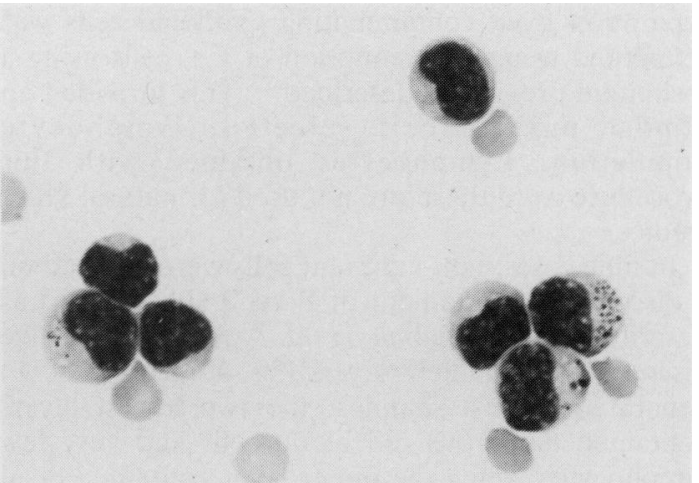

Figure Smears of human isolated intraepithelial lymphocytes. Three lymphocytes with granules variable in number and in size. May Grunwald Giemsa staining.

replication as only 0.4 to $0.8 \%$ (four studies) are labelled after one hour incubation with tritiated thymidine.

\section{MOST INTRAEPITHELIAL LYMPHOCYTES ARE OF} THE T LINEAGE AND BEAR T8 ANTIGEN (Table 1 ). The mean percentage of $\mathrm{E}(+)$ cells was $68 \pm 10 \%$ and that of $\mathrm{T} 3+$ lymphocytes $84 \pm 13 \%$. The percentage of $\mathrm{T} 8+$ lymphocytes $(68 \pm 15 \%)$ was constantly higher than that of T4+ lymphocytes $(10 \pm 5 \%)$. In each case, the total number of T4+ and $\mathrm{T} 8+$ cells was close to the number of $\mathrm{T} 3+$ cells. Three controls performed with peripheral blood lymphocytes handled as intraepithelial lymphocytes indicated that our isolation procedures (Ficoll as well as Percoll) had no effect upon either the percentage of $\mathrm{E}+$ cells or the distribution of the membrane phenotypes.

Most granular lymphocytes were observed to be $\mathrm{E}(+)$ cells. In a representative experiment, $14 \%$ of all intraepithelial lymphocytes and $20 \%$ of all $\mathrm{E}(+)$ cells isolated from the corresponding population were found to contain granules. Fewer than $3 \%$ of $\mathrm{E}(-)$ cells were granular lymphocytes. As shown in Table 1 , it is clear that in most experiments there was an overlap between the populations of T3+ cells and granular lymphocytes, indicating that at least some granular lymphocytes must belong to the $\mathrm{T} 3(+)$ cell population.

A simultaneous study of in vitro ${ }^{35} \mathrm{~S}$ uptake and of membrane markers showed that $\mathrm{T} 3+(6 \%)$ and $\mathrm{T} 8+$ (3\%) lymphocytes contained ${ }^{35} \mathrm{~S}$ labelled granules. The percentage of granular lymphocytes stained with May-Grunwald-Giemsa is therefore much higher than the number of isotopically labelled cells, but only the unquestionable labelled cells with large ${ }^{35} \mathrm{~S}(+)$ granules were counted. 
INTRAEPITHELIAL LYMPHOCYTES RARELY CONTAINED B LYMPHOCYTES OR MONOCYTIC CELLS

As shown in Table 1 , the percentage of cells containing immunoglobulins (iIg) was very low $(<1 \%)$. The percentage of lymphocytes bearing membrane $\mathrm{Ig}$ was likewise very low $(\leqslant 2 \%)$. The study of EAC rosetting cells provided the same results $(1 \cdot 5 \%)$. Controls with peripheral blood lymphocytes showed that the intraepithelial lymphocytes isolation procedure did not decrease significantly the number of $\mathrm{Ig}$ bearing or EAC rosetting cells. Neither DR(+) nor $\mathrm{M}_{1}(+)$ cells were seen in the two intraepithelial lymphocytes cell preparations studied.

HUMAN INTRAEPITHELIAL LYMPHOCYTES ARE

UNABLE TO EXERT A NATURAL KILLER

CYTOTOXICITY AGAINST K 562

As shown in Table 2, intraepithelial lymphocytes freshly isolated on Percoll gradient, showed no cytotoxic activity against the K 562 target.
Incubation with interferon $(10 \mathrm{U} / \mathrm{ml})$, or a PHAdepleted conditioned medium containing Il-2 (10\%) for 18 hours did not induce any cytotoxicity in intraepithelial lymphocytes, but increased the cytotoxicity of the peripheral blood lymphocytes. Artefactual absence of cytotoxicity due to the isolation procedure was discounted, because the same isolation procedure, including a gradient of Percoll, applied to peripheral blood lymphocytes did not decrease natural killer activity and even increased it (Table 2 legend). Natural killer activity was not detected when intraepithelial lymphocytes were isolated in medium containing $5 \times 10^{-7} \mathrm{M}$ indomethacin or $10^{-3} \mathrm{M}$ cimetidine (data not shown).

\section{Discussion}

Intraepithelial lymphocytes have been isolated from several animal species including mice, ${ }^{132}$ rats, ${ }^{3}$ rabbits ${ }^{4}$ and guinea pigs. ${ }^{5}$ In rodent Peyer's patches are macroscopically detectable and thus easily

Table 2 Natural killer cytotoxicity of human intraepithelial lymphocytes against $K 562$ target

\begin{tabular}{|c|c|c|c|c|c|c|c|}
\hline \multirow[b]{2}{*}{ Experiment } & \multirow{2}{*}{$\begin{array}{l}\text { Origin of tested } \\
\text { lymphocytes* }\end{array}$} & \multirow{2}{*}{$\begin{array}{l}\text { Incubation in } \\
\text { presence of }\end{array}$} & \multicolumn{5}{|c|}{ Ratio effector cells/target cells } \\
\hline & & & $100: 1$ & $50: 1$ & $25: 1$ & $12: 1$ & $6: 1$ \\
\hline 1 & IEL & $\mathrm{O}$ & 1 & 5 & 1.7 & 1 & 4 \\
\hline 2 & IEL & $\mathbf{M}$ & $2 \cdot 9$ & 0 & 0 & 0 & 0 \\
\hline \multirow[t]{7}{*}{3} & IEL & $\mathrm{O}$ & $1 \cdot 7$ & $2 \cdot 2$ & $1 \cdot 1$ & 3.8 & 1.7 \\
\hline & IEL & $\mathbf{M}$ & 1.9 & $2 \cdot 1$ & $2 \cdot 8$ & $2 \cdot 4$ & 3 \\
\hline & IEL & $\mathrm{CM}$ & $1 \cdot 9$ & $2 \cdot 3$ & $2 \cdot 8$ & $1 \cdot 8$ & $1 \cdot 9$ \\
\hline & Control PBL & $\mathrm{O}$ & 33 & 23 & 8 & 4 & 2 \\
\hline & Control PBL & $\mathbf{M}$ & NT & 23 & $14 \cdot 5$ & 9 & 4 \\
\hline & Control PBL & IFN & NT & 58 & 46 & 36 & 23 \\
\hline & Control PBL & $\mathrm{CM}$ & NT & 40 & 29 & 22 & 14 \\
\hline \multirow[t]{3}{*}{4} & IEL & $\mathbf{M}$ & NT & 0.7 & $0 \cdot 8$ & 0 & 0 \\
\hline & IEL & IFN & NT & $1 \cdot 3$ & $1 \cdot 5$ & 0 & 0 \\
\hline & Control PBL & $\mathbf{M}$ & $44 \cdot 6$ & 35 & 22 & 14 & $6 \cdot 7$ \\
\hline \multirow[t]{6}{*}{5} & IEL & $\mathrm{M}$ & $3 \cdot 3$ & $3 \cdot 1$ & 1 & $2 \cdot 5$ & $1 \cdot 5$ \\
\hline & IEL & IFN & $2 \cdot 3$ & $1 \cdot 7$ & 1 & $1 \cdot 4$ & 1.8 \\
\hline & Control PBL & $\mathbf{M}$ & NT & 40 & 27 & 22 & 14 \\
\hline & Control PBL & IFN & NT & 53 & 34 & 27 & 22 \\
\hline & Autologous PBL & $\mathbf{M}$ & NT & 45 & 40 & 26 & 17 \\
\hline & Autologous PBL & IFN & NT & 53 & 42 & 34 & 25 \\
\hline \multirow[t]{5}{*}{6} & IEL & IFN & 0.7 & $1 \cdot 1$ & 1.4 & 1 & 0 \\
\hline & Control PBL & $\mathbf{M}$ & NT & 36 & 32 & 12 & 6 \\
\hline & Control PBL & IFN & NT & 42 & 31 & 19 & 12 \\
\hline & Autologous PBL & $\mathbf{M}$ & NT & 60 & 53 & 35 & 25 \\
\hline & Autologous PBL & IFN & NT & 67 & 58 & 45 & 34 \\
\hline
\end{tabular}

* Intraepithelial lymphocytes (IEL) were isolated on Percoll gradient. Peripheral blood lymphocytes (PBL) were isolated on Ficoll-Hypaque gradient, as it was shown that treatment of peripheral blood lymphocytes with the procedure isolation used for intraepithelial lymphocytes did not modify their natural killer (NK) activity (PBL isolated on Ficoll-Hypaque, 52\%, 43\%, 31.5\%, 19\%, $10 \%$. Same peripheral blood lymphocytes isolated on glass wool column then Percoll, $56 \%, 56 \%, 54 \%, 37.5 \%, 28 \%$ at ratio from $100: 1$, $50: 1,25: 1,12: 1,6: 1$ respectively).

+ Cytotoxicity was studied without incubation $(\mathrm{O})$ or after 18 hours incubation in culture medium alone $(\mathrm{M})$ or added with $10 \mathrm{U} / \mathrm{ml}$ interferon (IFN) or with $10 \%$ PHA conditioned medium containing IL-2 (CM). 
removed, eliminating a source of contaminating cells. Human Peyer's patches are macroscopically undetectable and along with the lamina propria leukocytes are apparently responsible for the B cell contamination of human intraepithelial lymphocytes isolated by a procedure using EDTA to disrupt the epithelium. ${ }^{10}{ }^{11}$ In contrast, our mechanical method provided a pure population of intraepithelial lymphocytes. This population was not contaminated by Peyer's patches lymphocytes. Indeed, it contained practically no $B$ cells and it is unlikely that a large number of $B$ cells was removed during the isolation procedure, because no decrease was observed when the procedure was applied to peripheral blood lymphocytes. Besides, intraepithelial lymphocytes did not seem to be contaminated by lamina propria cells as the phenotype of the recovered cells was very similar to that described in the epithelium on tissue sections and because it was different from that observed in the lamina propria which contains a majority of $\mathrm{T}$ cells associated with the helper phenotype T4. ${ }^{6} 3334$

Human intraepithelial lymphocytes have peculiar morphological and cytochemical characteristics. About $25 \%$ (up to $54 \%$ ) of them contain intracytoplasmic granules, first observed by electron microscopy. 89 Intracytoplasmic granules of human intraepithelial lymphocytes appear similar to those described in the rabbit ${ }^{4}$ and in the mouse ${ }^{1}$ they stain with alcian blue and are metachromatic with toluidine blue. This, along with incorporation of radioactive sulphate (also observed more extensively in mice after in vivo injection ${ }^{1}$ ) suggests that presence of sulphated mucopolysaccharides such as occur in mast cell granules. Yet, unlike mast cells, human intraepithelial lymphocytes contain no histamine demonstrable by the orthophtaldialdehyde reaction. Small size of the granules, however, may be responsible for the negative reaction, because only a low content of histamine is demonstrable in the mouse, in circumstances where granules are very large, particularly in Beige mice. ${ }^{1}$ Human intraepithelial lymphocytes belong to the $T$ lineage as they form $E$ rosettes and they bear $T_{3}$ antigen. They preferentially express the phenotype associated with cytotoxic/suppressor $\mathrm{T}$ cell subset (T8). T3 and T8 antigens were also shown on intraepithelial lymphocytes that contain granules labelled with ${ }^{35} \mathrm{~S}$. The presence of sulphate containing granules in $\mathrm{T} 4+$ intraepithelial lymphocytes cannot, however, be ruled out by our labelling experiments because only the largest granules may have been labelled. Indeed, studies in immunoelectron microscopy reveal the presence of granules of similar appearance in both $\mathrm{T} 4+$ and T8+ intraepithelial lymphocytes. ${ }^{34}$ It is not known whether the granules have a different content in both $T$ cell subsets. Finally, as with mouse intraepithelial lymphocytes, ${ }^{1}$ human intraepithelial lymphocytes have a low rate of replication when labelled in vitro by tritiated thymidine. Our observations indicate that as in mice ${ }^{2}$ and rats, ${ }^{23}$ the human intraepithelial lymphocytes are a unique lymphocyte population with regard to the number of granules and the high percentage of the lymphocytes bearing the $\mathrm{T}$ suppressor-cytotoxic phenotype.

The function of these lymphocytes has not yet been defined. Their possible role as an effector of natural cytotoxicity is suggested by their resemblance to the large granular lymphocytes which are the main effector cells of natural killer activity in the peripheral blood of humans, ${ }^{18}$ rats, ${ }^{35}$ and mice. ${ }^{36}$ Natural killer activity was detected among intraepithelial lymphocytes of the guinea pig, ${ }^{5}$ and of the young mouse ${ }^{19}{ }^{20}$ This activity is, however, low considering the high percentage of granular lymphocytes in intraepithelial lymphocytes populations. Yet natural killer activity is often low in rodents, regardless of the target assayed. In man Chiba et $a l^{1 \mathrm{P}}$ failed to show any spontaneous cytotoxicity of colonic intraepithelial lymphocytes against Chang target cells. These authors observed that the EDTA used in their isolation procedure may have impaired this activity.

As K 562 cells have been shown to be in man the best target for human peripheral blood large granular lymphocytes, it was of particular interest to compare human intraepithelial lymphocytes with peripheral blood lymphocytes, assayed against this target. We did not detect any cytotoxicity against K 562 among intraepithelial lymphocytes, while peripheral blood lymphocytes exerted a strong natural killer activity. Moreover, an 18 hour incubation of intraepithelial lymphocytes with natural killer potentiators, interferon ${ }^{23} 24$ and Il-2, ${ }^{24}$ induced no discernible cytotoxicity. This absence of natural cytotoxicity may be because of the release of inhibitory substances during the isolation procedure. ${ }^{37}$ In our hands, however, the same procedure applied to peripheral blood lymphocytes did not decrease the cytotoxicity of these cells. Furthermore, the addition of indomethacin, or cimetidine, which inhibit the suppressive effects of prostaglandin $E_{2}$, or of histamine, respectively, did not allow for the detection of any intraepithelial lymphocytes mediated natural cytotoxicity, though it cannot be completely excluded that some other inhibitory substances, or some cellular suppressor of natural killer activity may be present in the intestinal tissue taken from the proximity of a malignant tumour. Failure to show natural killer activity in human intraepithelial lymphocytes raises the 
question whether this is because of the absence of natural killer cells in the epithelium, or of their inability to exert a cytotoxic function. A recent observation showing that intraepithelial lymphocytes do not express the surface antigens present on the peripheral blood large granular lymphocytes with natural killer activity - that is, Leu 7, T10 and $M_{1}$ antigens - suggests that human intraepithelial lymphocytes do not contain natural killer cells. ${ }^{34}$

Thus the specific role of these lymphocytes and the function of their granules remain to be defined, as do their possible relationships with peripheral blood large granular lymphocytes with natural killer activity. Though having the phenotype of cytotoxic $T$ cells they have, in mice, less specific cytotoxic capabilities than lamina propria lymphocytes which contain only a minority of lymphocytes with this phenotype. ${ }^{38}$ Their possible suppressive activity is poorly documented. It has also been suggested that a relationship may exist between the presence of the intraepithelial lymphocytes and the regulation of epithelial renewal ${ }^{16} 17$ but the mechanism of this action is not yet known. At present the function of these peculiar lymphocytes remains unknown.

We thank Dr F Preffer for help in preparation of the manuscript and $M$ Malassis-Seris for technical advice. This work was supported by L'Institui National de la Sante et de la Recherche Medicale.

\section{References}

1 Guy-Grand D, Griscelli C, Vassalli P. The mouse gut T lymphocyte, a novel type of $T$ cell. Nature, origin and traffic in mice in normal and graft-versus-host conditions. J Exp Med 1978; 148: 1661-77.

2 Guy-Grand D, Vassalli P. Nature and function of gut granulated T lymphocytes. Recent advances in mucosal immunity. New York: Raven Press, 1982: 23: 301-12.

3 Lyscom N, Brueton MJ. Intraepithelial, lamina propria and Peyer's patch lymphocytes of the rat small intestine: isolation and characterization in terms of immunoglobulin markers and receptors for monoclonal antibodies. Immunology 1982; 45: 775-83.

4 Rudzik O, Bienenstock J. Isolation and characteristics of gut mucosal lymphocytes. Lab Invest 1974; 30: $260-6$.

5 Arnaud-Battandier F, Bundy BM, O'Neill M et al. Cytotoxic activities of gut mucosal lymphoid cells in guinea pigs. J Immunol 1978; 121: 1059-65.

6 Selby WS, Janossy G, Goldstein G et al. T lymphocyte subsets in human intestinal mucosa: the distribution and relationship to MHC-derived antigens. Clin Exp Immunol 1981; 44: 453-8.

7 Flores AF, Winter HS, Bhan AK. In vitro model to assess immunoregulatory $\mathrm{T}$ lymphocyte subpopulations in gluten sensitive enteropathy. [Abstract] Gastroenterology 1982; 82: 1058.

8 Meader RD, Landers DF, Electron and light microscopic observations on relationships between lymphocytes and intestinal epithelium. Am J Anat 1967; 121: 763-74.

9 Toner PG, Ferguson A. Intraepithelial cells in the human intestinal mucosa. J Ultrastruct Res 1971; 34: 329-44.

10 Bartnik W, ReMine SG, Chiba $M$ et al. Isolation and characterization of colonic intraepithelial and lamina proprial lymphocytes. Gastroenterology 1980; 78: 97685.

11 Chiba M, Bartnik W, ReMine SG et al. Human colonic intraepithelial and lamina proprial lymphocytes: cytotoxicity in vitro and the potential effects of the isolation method on their functional properties. Gut 1981; 22: 177-86.

12 Glaister JR. Factors affecting the lymphoid cells in the small intestinal epithelium of the mouse. Int Arch Allergy Appl Immunol 1973; 45: 719-30.

13 Horowitz S, Lorenszonn VW, Olsen WA et al. Small intestinal disease in T cell deficiency. J Pediatr 1974; 85: $457-62$.

14 Ferguson A. Intraepithelial lymphocytes of the small intestine. Gut 1977; 18: 921-37.

15 Phillips AD, Rice SJ, France NE et al. Small intestinal intraepithelial lymphocyte levels in cow's milk protein intolerance. Gut 1979; 20: 509-12.

16 McIntosh Mowat A, Ferguson A. Hypersensitivity reactions in the small intestine. 6 . Pathogenesis of the graft-versus-host reaction in the small intestinal mucosa of the mouse. Transplantation 1981; 32: 238-43.

17 Guy-Grand D, Vassalli P. Gut mucosal lymphocyte subpopulations and mast cells. In: Ogral L, Jacobs DM, eds. Regulation of the immune response. 8th convoc. Immunol. New York, Amherst, Basel, Karger, 1982: $122-30$.

18 Timonen T, Ortaldo JR, Herberman RB. Characteristics of human large granular lymphocytes and relationship to natural killer and $\mathrm{K}$ cells. $J$ Exp Med 1981; 153: 569-82.

19 Tagliabue A, Luini W, Soldateschi D et al. Natural killer activity of gut mucosal lymphoid cells in mice. Eur J Immunol 1981; 11: 919-22.

20 Tagliabue A, Befus AD, Clark DA et al. Characteristics of natural killer cells in the murine intestinal epithelium and lamina propria. $J$ Exp Med 1982; 155: 1785-96.

21 Plaut M, Lichtenstein LM, Henney CS. Properties of a subpopulation of $T$ cells bearing histamine receptors. $J$ Clin Invest 1975; 55: 856-74.

22 Tracey DE, Adkinson Jr NF. Prostaglandin synthesis inhibitors potentiate the BCG-induced augmentation of natural killer cell activity. J Immunol 1980; 125: 136-141.

23 Senik A, Gresser I, Maury C et al. Enhancement by interferon of natural killer cell activity in mice. Cell Immunol 1979; 44: 186-200.

24 Kuribayaski K, Gillis S, Kern DE et al. Murine NK cell cultures: effects of interleukin-2 and interferon on cell growth and cytotoxic reactivity. J Immunol 1981; 126: 
2321-7.

25 Bentwich Z, Douglas SD, Siegal FP et al. Human lymphocyte-sheep erythrocyte rosette formation. Some characteristics of the interaction. Clin Immunol Immunopathol 1973; 1: 511-22.

26 Bianco C, Patrick R, Nussenzweig V. A population of lymphocytes bearing a membrane receptor for antigenantibody-complement complexes. I. Separation and characterization. J Exp Med 1970; 132: 702-20.

27 Grey HM, Rabellino E, Pirofsky B. Immunoglobulins on the surface of lymphocytes. IV distribution in hypogammaglobulinemia, cellular immunodeficiency, and chronic lymphatic leukemia. J Clin Invest 1971; 50: 2368-75.

28 Reinherz EL, Schlossman SF. The differentiation and function of human T lymphocytes. Cell 1980; 19: 821-7.

29 Breard J, Reinherz EL, Kung P et al. A monoclonal antibody reactive with human peripheral blood monocytes. J Immunol 1980; 124: 1943-8.

30 Zarling JM, Kung PC. Monoclonal antibodies which distinguish between human NK cells and cytotoxic T lymphocytes. Nature 1980; 288: 394-6.

31 Lipinski M, Virelizier JL, Tursz T et al. Natural killer and killer cell activities in patients with primary immunodeficiencies or defects in immune interferon production. Eur J Immunol 1980; 10: 246-9.
32 Davies MDJ, Parrot DMV. Preparation and purification of lymphocytes from the epithelium and lamina propria of murine small intestine. Gut 1981; 22: 481-8.

33 Selby WS, Janossy G, Jewell DP. Immunohistological characterization of intraepithelial lymphocytes of the human gastrointestinal tract. Gut 1981; 22: 169-76.

34 Cerf-Bensussan N, Schneeberger EE, Bhan AK. Immunohistologic and immunoelectron microscopic characterization of the mucosal lymphocytes of human small intestine by the use of monoclonal antibodies. $J$ Immunol 1983; 130: 2615-22.

35 Reynolds CW, Timonen TT, Holden HT et al. Natural Killer cell activity in the rat. Analysis of effector cell morphology and effects of interferon on natural killer cell function in the athymic (nude) rat. Eur J Immunol 1982; 12: 577-82.

36 Luini W, Boraschi D, Alberti S et al. Morphological characterization of a cell population responsible for natural killer activity. Immunology 1981; 43: 663-8.

37 Bland PW, Richens ER, Birtton DC et al. Isolation and purification of human large bowel mucosal lymphoid cells: effect of separation technique on functional characteristics. Gut 1979; 20: 1037-46.

38 Davies MDJ, Parrot DMV. Cytotoxic T cells in small intestine epithelial, lamina propria and lung lymphocytes. Immunology 1981; 44: 367-71. 